\title{
SPECYFIKA ZMILITARYZOWANEGO AKTORA NIEPAŃSTWOWEGO WE WSPÓLCZESNYCH STOSUNKACH MIĘDZYNARODOWYCH. PRZYPADEK HEZBOLLAHU
}

Celem artykułu jest scharakteryzowanie i przedstawienie specyfiki aktywności uczestników niepaństwowych, którzy w swoim działaniu wykorzystują środki militarne. Autor podjął się próby zdefiniowania i sklasyfikowania ,zmilitaryzowanego aktora niepaństwowego", obejmującego szeroką grupę uczestników niepaństwowych. Za modelowy przykład tego rodzaju uczestnika posłużył libański Hezbollah („Partia Boga”), który od początku swojego istnienia posiada skrzydło zbrojne i wykazuje się intensywną aktywnością międzynarodową.

\section{UCZESTNICY NIEPAŃSTWOWI W ZMIENIAJĄCYM SIĘ ŚRODOWISKU MIĘDZYNARODOWYM}

Upadek systemu bipolarnego znalazł głębokie odzwierciedlenie w rzeczywistości międzynarodowej. Utrwalone dotychczas więzi i zależności zaczęły się rozpadać, a w ich miejsce pojawiły się nowe, świadczące o daleko idących przewartościowaniach w polityce międzynarodowej. Państwa zostały zmuszone do reorientacji w swojej polityce zagranicznej, chcąc efektywnie stawiać czoła nowym wyzwaniom. Pojawienie się procesów globalizacji i utrwalanie się regionalizmu wymusiło na państwach zakrojoną na większą niż dotychczas skalę kooperację w celu rozwiązywania problemów uniwersalnych takich jak m.in. terroryzm międzynarodowy, ochrona środowiska czy poszanowanie praw człowieka. Jednocześnie dynamicznie rozwijające się procesy transnarodowe, których cechą charakterystyczną jest wzrost współzależności między aktorami na płaszczyźnie polityki pozapaństwowej, zaczęły prowadzić do zjawiska deterytorializacji państwa, polegającego na utracie kontroli nad procesami zachodzącymi na jego terytorium, co podważa tradycyjne pojmowanie suwerenności państwa ${ }^{l}$. Tym samym zaczęto wskazywać na „osłabienie” statusu państwa w stosunkach międzynarodowych.

Na tym tle istotnym zmianom zaczął także podlegać status i aktywność uczestników niepaństwowych, których znaczna część stała się beneficjentem przewartościowań

1 Na temat problemów współczesnego pojmowania suwerenności państwa zob.: T. Łoś-Nowak, Stosunki międzynarodowe. Teorie - systemy - uczestnicy, Wrocław 2006, s. 154-158, 252-257; R. Kuźniar, Polityka i siła. Studia strategiczne. Zarys problematyki, Warszawa 2005, s. 266; A. Rothert, Państwo postsuwerenne, „Studia Politologiczne” 2010, vol. 17, s. 212-224. 
w stosunkach międzynarodowych, jakie zaszły w ostatnich dwudziestu latach. Szczególnie należy wymienić tu uczestników transnarodowych: korporacje, banki, fundacje, ale także i zorganizowane ugrupowania przestępcze i organizacje terrorystyczne. W swojej działalności wykorzystują oni redukcję znaczenia granic państwowych oraz szybko postępujący proces informatyzacji życia. Sfera cyberprzestrzeni stała się dla wielu uczestników transnarodowych naturalnym środowiskiem funkcjonowania.

Obecnie już dość bogatą tradycję ma dyskurs na temat roli i miejsca korporacji transnarodowych we współczesnym świecie, szczególnie w odniesieniu do pozycji państwa. Od wielu lat zauważa się dynamiczny wzrost potencjału finansowego korporacji, których majątek często przekracza wielkość budżetów wielu państw². Jak wskazuje Janusz Symonides, w obecnej dobie największe korporacje są zdolne do zawierania umów, które wprawdzie nie mają formalnie charakteru umów międzynarodowych, lecz dla wielu państw są o wiele bardziej istotne niż umowy międzypaństwowe czy umowy z organizacjami międzynarodowymi. Ponadto korporacje posiadają instrumenty oddziaływania na politykę i gospodarkę państwa, decydując o rynku kapitałowym i finansowym i wpływając na pozycję waluty i bilans handlowy ${ }^{3}$. Niewątpliwie powoduje to, że korporacje są podmiotami, które odgrywają kluczową rolę w procesie kształtowania współczesnego rynku i determinują polityczno-gospodarcze relacje zachodzące na arenie międzynarodowej ${ }^{4}$. Rodzi to pytania o przyszłą pozycję korporacji w stosunkach międzynarodowych. Adam Gwiazda trafnie zauważa, że z jednej strony ekspansja korporacji jest dla wielu państw szansą na rozwój i postęp, z drugiej zaś można w tym upatrywać zagrożenie dla tradycyjnego statusu państwa w stosunkach międzynarodowych $^{5}$. Katarzyna Marzęda-Młynarska pisze wręcz o fenomenie korporacji międzynarodowych, w których działalności zaciera się granica między sferą gospodarczą a polityką. W ten sposób korporacje stały się uczestnikami quasi-politycznymi ${ }^{6}$.

Obok korporacji na szczególną uwagę zasługuje rozwój transnarodowej aktywności wszelkich grup przestępczych czy organizacji terrorystycznych. Podobnie jak w przypadku korporacji, podmioty te, które wykazują cechy charakterystyczne swej transnarodowej działalności, opierają się na strukturze sieciowej i wykorzystują łatwość w przenikaniu przez granice państw i w nawiązywaniu współpracy na skalę globalną. Duża liczba związanych ze sobą grup i rozłożystość sieci transnarodowych powiązań powoduje, że państwa współcześnie mają spore trudności w neutralizowaniu

2 Ranking największych 500 korporacji w 2011 roku: http://money.cnn.com/magazines/fortune/global500/2011/full_list/index.html (20.10.11).

3 J. Symonides, Państwo w procesie globalizacji, w: Państwo w teorii i praktyce stosunków międzynarodowych, red. J. Symonides, M. Sułek, Warszawa 2009, s. 162-193.

4 Szerzej zob.: A. Moraczewska, Korporacje transnarodowe w procesach globalizacji, w: Oblicza procesów globalizacji, red. M. Pietraś, Lublin 2002, s. 85-103; J. Kukułka, Wstęp do nauki o stosunkach międzynarodowych, Warszawa 2003, s. 113-116; M. Pietraś, K. Piórko, Podmioty transnarodowe, w: Międzynarodowe stosunki polityczne, red. M. Pietraś, Lublin 2006, s. 139-165.

5 A. Gwiazda, Czy korporacje ponadnarodowe zagrażaja państwom narodowym?, „Gdańskie Studia Międzynarodowe" 2003, nr 2, s. 115-128.

${ }^{6}$ K. Marzęda-Młynarska, Korporacje międzynarodowe: nowy fenomen w polityce międzynarodowej, w: Polityka zagraniczna. Aktorzy - potencjaty - strategie, red. T. Łoś-Nowak, Warszawa 2011, s. 239. 
ośrodka ciężkości takiej sieci ${ }^{7}$. Wykorzystując ten atut międzynarodowe grupy przestępcze czy nawet organizacje terrorystyczne są bardziej elastyczne w swoim funkcjonowaniu od państw i w efekcie eliminacja jednego ogniwa takiego podmiotu nie prowadzi do zaprzestania jego działalności.

Rozwój aktywności uczestników niepaństwowych przyczynił się do powstania sytuacji, w której obok sfery stosunków międzypaństwowych rozwinęła się wręcz niezależna od niej sfera wzajemnych relacji uczestników niepaństwowych. Zjawisko takie pogłębia istniejąca już hybrydowość w stosunkach międzynarodowych, w której ramach występują tradycyjne zasady funkcjonowania i jednocześnie jakościowo nowe procesy. Stanowi to istotę późnowestfalskiego ładu międzynarodowego ${ }^{8}$.

\section{ZMILITARYZOWANY AKTOR NIEPAŃSTWOWY}

W literaturze przedmiotu występuje powszechnie przyjmowany podział uczestników stosunków międzynarodowych na dwie grupy: uczestników państwowych i niepaństwowych (pozapaństwowych) ${ }^{9}$. Powoduje to, że w pierwszej grupie znajdują się wyłącznie państwa, zaś w drugiej zawierają się wszyscy pozostali uczestnicy stosunków międzynarodowych (narody, organizacje i ruchy międzynarodowe, aktorzy transnarodowi i aktorzy subpaństwowi). Uczestników niepaństwowych cechuje jednak daleko idąca różnorodność i coraz większa trudność w jednolitej ich klasyfikacji.

Według Petera Willetsa aktor niepaństwowy to „termin szeroko rozpowszechniony w odniesieniu do każdego aktora niebędącego państwem, choć nierozstrzygnięta pozostaje kwestia obejmowania nim takich podmiotów jak Organizacja Narodów Zjednoczonych $(\mathrm{ONZ}){ }^{, 10}$. Z kolei Daphné Josselin i William Wallace proponują dość rozbudowaną i ciekawą definicję aktora niepaństwowego, według których jest on „W większości, bądź całkowicie niezależny od funduszy i kontroli rządu centralnego; wywodzi się ze społeczeństwa obywatelskiego lub z gospodarki wolnorynkowej, bądź jest pochodną politycznych impulsów spoza kierunku działania i kontroli państwa; operuje lub partycypuje w sieciach rozprzestrzeniających się ponad granicami dwóch lub więcej państw, współtworząc relacje transnarodowe i wiążąc ze sobą systemy polityczne, gospodarki i społeczeństwa; działa tak, że wpływa na rezultaty politycznych zjawisk w obrębie jednego, bądź więcej państw lub w ramach instytucji

7 Szerzej zob.: P. Williams, Strategia dla Nowego Świata: zwalczanie terroryzmu i transnarodowej przestępczości, w: Strategia we współczesnym świecie. Wprowadzenie do studiów strategicznych, red. J. Baylis, J. Wirtz, C. S. Gray, E. Cohen, Kraków 2009, s. 214-215.

${ }_{8}$ Zob. szerzej: M. Pietraś, Hybrydowość późnowestfalskiego ładu międzynarodowego, w: Późnowestfalski ład międzynarodowy, red. M. Pietraś, K. Marzęda, Lublin 2008, s. 57-74.

9 Zob.: I. Popiuk-Rysińska, Uczestnicy stosunków międzynarodowych, ich interesy i oddziaływania, w: Stosunki międzynarodowe: geneza, struktura, dynamika, red. E. Haliżak, R. Kuźniar, Warszawa 2000, s. 88; oraz Wspótczesne stosunki międzynarodowe, red. T. Łoś-Nowak, Wrocław 2008, s. $53-74$.

10 P. Willetts, Aktorzy transnarodowi i organizacje międzynarodowe w polityce globalnej, w: Globalizacja polityki światowej. Wprowadzenie do stosunków międzynarodowych, red. J. Baylis, S. Smith, Kraków 2008, s. 525. 
międzynarodowych, co jest jego głównym celem, bądź jednym z wielu aspektów jego działalności" 11 .

Zarówno pierwsza, bardzo ogólna, jak i druga o wiele szersza definicja budzą wiele wątpliwości. P. Willetts nie kwestionuje traktowania rządowych organizacji międzynarodowych jako uczestników niepaństwowych. Natomiast proponuje on w ramach pojęcia uczestnika niepaństwowego wyraźnie rozdzielać ich na „aktorów transnarodowych” i ,organizacje międzynarodowe" 12 . Daphné Josselin i William Wallace w swojej definicji uczestnika niepaństwowego niemalże odrzucają przy jego powstawaniu pierwiastek państwowy, wskazując przy tym na silne oddziaływanie aktora niepaństwowego na politykę państwa i koncentrując się na jego transnarodowej aktywności. Zatem dylemat uznawania za uczestnika niepaństwowego rządowych organizacji międzynarodowych, które są powoływane przez państwa i realizują ich politykę zagraniczną, ale nie są państwami, stanowi jedną z ważniejszych kwestii dyskusyjnych. Podobnie jak w przypadku kontrowersji wokół rządowych organizacji międzynarodowych można wyróżnić grupę podmiotów, które w swoim funkcjonowaniu przypominają państwo, lecz przez państwa nie są powszechnie uznawane - tzw. quasi-państwa. Ponadto przy tej okazji powinno się również wskazać na zjawisko hybrydowości niepaństwowych uczestników stosunków międzynarodowych, które nie tyle utrudnia definiowanie aktora niepaństwowego, co narusza tradycyjny podział wśród uczestników niepaństwowych. Zjawisko to polega na łączeniu przez uczestnika niepaństwowego wielu różnych cech, charakterystycznych dla określonych grup uczestników niepaństwowych. I tak dla przykładu np. uczestnik subpaństwowy, może być jednocześnie ujmowany w kategoriach uczestnika transnarodowego ${ }^{13}$.

Podobnie jak wiele trudności sprawia definiowanie uczestnika niepaństwowego, tak samo niełatwym zadaniem jest próba sformułowania terminu określającego wybraną na potrzebę analizy grupę uczestników niepaństwowych. W literaturze anglojęzycznej funkcjonuje termin violent non-state actors definiujący zbrojne grupy niepaństwowe, które w swoim działaniu odwołują się do stosowania zorganizowanej przemocy jako narzędzia realizacji swoich celów ${ }^{14}$. Jednak w ocenie autora termin ten jest węższy od określenia „zmilitaryzowany aktor niepaństwowy”, bowiem nie wszystkie podmioty zmilitaryzowane i niepaństwowe odwołują się do stosowania zorganizowanej przemocy. Zatem na bazie powyższych rozważań, za zmilitaryzowanego aktora niepaństwowego można uznać każdego uczestnika niepaństwowego, który dysponuje siłami zbrojnymi, bądź w swoim działaniu posługuje się bronią i wykazuje aktywność międzynarodową.

11 D. Josselin, W. Wallace, Non-State Actors in World Politics: a Framework, w: Non-State Actors in World Politics, eds. D. Josselin, W. Wallace, New York 2001, s. 3-4.

12 P. Willetts, op. cit., s. 525. Podobnie w dualistyczny sposób podział ten ujmuje Elke Krahmann, dzieląc uczestników niepaństwowych na dwie grupy: aktorów niepaństwowych (w oryg. private actors) i organizacje międzyrządowe (intergovernmental organizations). Zob.: E. Krahmann, From State to Non-State Actors: The Emergence of Security Governance, w: New Threats and New Actors in International Security, ed. E. Krahmann, Gordonsville 2005, s. 8.

13 Przykładem tego jest analizowany w opracowaniu Hezbollah o czym w dalszej części artykułu.

14 K. Mulaj, Violent non-State Actors: Exploring Their State Relations, Legitimation and Operationality, w: Violent Non-State Actors in World Politics, ed. K. Mulaj, New York 2010, s. 3. 
Zgodnie z powyższą definicją do grupy uczestników określanych mianem zmilitaryzowanego aktora niepaństwowego można zaliczyć ${ }^{15}$ :

- międzynarodowe organizacje (grupy) przestępcze, które w swojej działalności stosują zbrojną przemoc (gangi, mafie, kartele narkotykowe, a także najemnicy i piraci);

- zbrojne ugrupowania podlegające lokalnym watażkom;

- ruchy narodowo-wyzwoleńcze ${ }^{16}$;

- ruchy społeczne o charakterze zbrojnym ${ }^{17}$;

- organizacje terrorystyczne;

- partie polityczne, które dysponują skrzydłem zbrojnym;

- prywatne firmy wojskowe ${ }^{18}$;

- kontyngenty sił zbrojnych organizacji międzynarodowych.

Jak można zauważyć grupa zmilitaryzowanych uczestników niepaństwowych jest bardzo różnorodna. Zawierają się w niej uczestnicy subpaństwowi (np. partie polityczne ze swoim skrzydłem zbrojnym), jak i transnarodowi (np. transnarodowe ugrupowania przestępcze). Podobnie jak w przypadku definicji uczestnika niepaństwowego kwestią dyskusyjną jest tutaj obecność kontyngentów sił zbrojnych (np. pokojowych sił ONZ, czy sił wojskowych NATO). Wszakże są to siły państw, które wykonują misje pod auspicjami rządowej organizacji międzynarodowej.

Praktycznie każdy ze zmilitaryzowanych uczestników niepaństwowych realizuje, bądź w swojej działalności może realizować określone cele polityczne. Najbardziej aktywne w sferze działań politycznych są: ruchy narodowo-wyzwoleńcze, partie polityczne ze skrzydłem zbrojnym, organizacje terrorystyczne, zbrojne ugrupowania podlegające lokalnym watażkom, a także kontyngenty sił zbrojnych organizacji międzynarodowych, które np. w przypadku ONZ m.in. pełnią funkcję stabilizacyjną w celu przywracania pokoju na terytoriach ogarniętych konfliktem. Wszelkie międzynarodowe organizacje i grupy przestępcze, włączając w to piratów i najemników, głównie są nastawione na zysk, a więc cele ich działania mają charakter ekonomiczny. Podobnie należy rozpatrywać działalność prywatnych firm wojskowych, szczególnie zatrudnianych przez korporacje międzynarodowe do ochrony własnej infrastruktury i pracowników.

W zasadzie współcześni zmilitaryzowani uczestnicy niepaństwowi dysponują szeroką gamą rodzajów posiadanej przez siebie broni. Niewielkie międzynarodowe organizacje przestępcze mogą dysponować niedużym arsenałem broni, większe jak np.

15 Dla porównania Klejda Mulaj do grupy violent non-state actors zaliczył: 1) ruchy narodowo-wyzwoleńcze lub/i ruchy separatystyczne, 2) grupy rebelianckie, 3) organizacje terrorystyczne, 4) milicje składające się z nieregularnych ale znaczących sił zbrojnych włącznie z grupami podlegającymi lokalnych watażkom i siłami paramilitarnymi operującymi na obszarze niekontrolowanym przez rząd centralny, 5) grupy najemników (włącznie z prywatnymi firmami wojskowymi). Ibidem, S. $3-4$.

16 W zależności od oceny politycznej mogą być one określane jako ruchy separatystyczne lub nawet jako organizacje terrorystyczne.

${ }_{17}$ Dobry przykład stanowi tutaj salaficki ruch globalnego dżihadu, którego specyfikę i istotę funkcjonowania przedstawił Artur Wejkszner. Zob.: A. Wejkszner, Ewolucja terroryzmu motywowanego ideologia religijna na przyktadzie salafickiego ruchu globalnego dżihadu, Poznań 2010.

18 Należy tu wyraźnie rozróżnić klasycznie pojmowanych najemników od prywatnych firm wojskowych, które są zarejestrowane i działają w sposób legalny. Szerzej zob.: Ł. Szozda, Prywatne firmy wojskowe, „Bezpieczeństwo Narodowe” 2006, nr 2, s. 206-218. 
kolumbijskie kartele narkotykowe, które posiadają zaawansowany technologicznie sprzęt są w stanie prowadzić wyrównane walki z siłami rządowymi. Siły zbrojne lokalnych watażków, które mogą zrzeszać tysiące żołnierzy posiadają uzbrojenie podobne do tego jakim dysponują armie państw. Z reguły jest to broń, która np. przed wybuchem wojny domowej i upadkiem państwa była na wyposażeniu armii państwowej. Na szczególną uwagę zasługują dynamicznie rozwijające się prywatne firmy wojskowe jak np. Blackwater Worldwide, która ma siedzibę na terytorium USA i posiada nowoczesne ośrodki treningowe oraz dysponuje zaawansowanym sprzętem wojskowym, włącznie z helikopterami i transporterami opancerzonymi.

W recepcji społecznej zmilitaryzowany aktor niepaństwowy jest z reguły negatywnie odbierany. Z przemocą i stanem zagrożenia kojarzą się organizacje terrorystyczne, międzynarodowe ugrupowania przestępcze czy zbrojne ugrupowania podlegające lokalnym watażkom. Natomiast pozytywnie mogą być odbierane ruchy narodowo-wyzwoleńcze. Ten dualistyczny podział na „złych” i „dobrych” ma swoje odniesienie w literaturze przedmiotu, gdzie np. organizacja pozarządowa jest postrzegana jako ten „dobry” uczestnik niepaństwowy, zaś organizacja terrorystyczna jest uznawana za „złego”. P. Willetts dodatkowo wskazuje na możliwość zmiany tego „statusu”, przeobrażając się ze „złych”, czyli terrorystycznych w „,dobre” - narodowowyzwoleńcze ${ }^{19}$.

\section{HEZBOLLAH JAKO UCZESTNIK STOSUNKÓW MIĘDZYNARODOWYCH. DYLEMATY TERMINOLOGICZNE}

Hezbollah od początku swojego powstania w 1982 r. przeszedł daleko idącą ewolucję w zakresie swojej działalności i realizacji celów. W pierwszym etapie Hezbollah funkcjonował jako formacja zbrojna założona przy pomocy około 1500 członków Korpusu Strażników Rewolucji Irańskiej (pasdaran) i podczas trwającej od 1975 r. wojny w Libanie przeprowadzał ataki terrorystyczne na siły międzynarodowe (ang. Multinational Force in Lebanon-MFL) i wojska izraelskie okupujące południowy Liban ${ }^{20}$. Po zakończeniu wojny w Libanie Hezbollah nie dokonał rozbrojenia i zaczął rozbudowywać swoje skrzydło polityczne. Z innymi ugrupowaniami politycznymi współuczestniczył w odbudowie libańskiej sceny politycznej i wystartował w 1992 r. w wyborach parlamentarnych. Od tamtego czasu Hezbollah regularnie uczestniczył jako partia polityczna we wszystkich wyborach do parlamentu oraz w wyborach municypalnych. Po wyborach parlamentarnych z 2005 r. po raz pierwszy w swojej historii „Partia Boga” otrzymała dwa stanowiska ministerialne (Mohammed Fnajsz - ministerstwo energii

19 P. Willetts, op. cit., s. 535.

20 Do największych ataków przeprowadzonych przez Hezbollah w pierwszych latach jego istnienia należy zaliczyć: atak na ambasadę USA w Bejrucie z 18 kwietnia 1983 r. (80 ofiar); na koszary żołnierzy amerykańskich (241 ofiar) i na koszary żołnierzy francuskich (80 ofiar) z 23 października 1983 r. Nie ma jednak zgodności co do liczby ofiar, w wielu źródłach występują rozbieżności. Zob. szerzej: R. Wright, Sacred Rage. The Wrath of Militant Islam, New York 2001, s. 72; A. N. Hamzeh, In the Path of Hizbullah, New York 2004, s. 82; J. P. Harik, Hezbollah. The Changing Face of Terrorism, London-New York 2004, s. 36. 
i wody; Trad Hamadeh - ministerstwo pracy) ${ }^{21}$. Obecnie w uformowanym w czerwcu 2011 r. rządzie Nadżiba Mikatiego ministrowie z ramienia Hezbollahu również kierują dwoma ministerstwami (Hussein Hadżdż Hassan - ministerstwo rolnictwa i Mohammed Fnajsz - ministerstwo ds. reform administracyjnych). Większość w rządzie Mikatiego posiada koalicja Ruchu 8 Marca (arab. Tahaluf 8 Azar), do której należy Hezbollah, który po raz pierwszy w historii współczesnego Libanu znalazł się w obozie rządzącym. Ponadto Hezbollah od wielu lat posiada bardzo rozbudowany system pomocy społecznej. W ramach jego struktury funkcjonuje wiele komitetów i fundacji, które realizują tysiące projektów takich jak: budowa szpitali, szkół, odbudowa zniszczonych domów, pomoc finansowa dla najuboższych ${ }^{22}$. Skala tej działalności jest ogromna. Hezbollah wykonuje usługi w stosunku do ok. 10\% ludności Libanu, efektywnie zastępując $w$ tej roli państwo libańskie ${ }^{23}$.

Hezbollah zatem funkcjonuje na wielu różnorodnych płaszczyznach i nie stanowi podmiotu jednoznacznego w swojej ocenie. Często w literaturze przedmiotu, jak i w materiałach publicystycznych jego aktywność jest spłycana do roli wyłącznie militarnej z dużym naciskiem na zagrożenie dla bezpieczeństwa międzynarodowego. Stąd Hezbollah jest określany mianem „organizacji terrorystycznej”, „milicji”, czy „grupy rebeliancko-partyzanckiej”, chociaż sami liderzy Hezbollahu podkreślają, że „Partia Boga” jest „ruchem oporu” prowadzonym przeciwko Izraelowi i jego sojusznikom. Żadne z tych określeń nie oddaje jednak pełnej podmiotowości i aktywności Hezbollahu. Należy zachować umiarkowany krytycyzm wobec określania Hezbollahu mianem „ruchu oporu”. Tym bardziej, że w maju 2000 r. Izrael wycofał się z południowego Libanu likwidując tym samym istniejącą od 1985 r. „strefę buforową”. Jednak „Partia Boga" w dalszym ciagu wysuwa roszczenia wobec Izraela m.in. do znajdujących się w jego granicach Farm Sziba'a. Z tego powodu w przekonaniu Hezbollahu istnieje ciagła potrzeba prowadzenia ruchu oporu wobec okupanta.

Podobnie należy traktować określanie Hezbollahu jako organizacji terrorystycznej, które obecnie jest bezpodstawne i ma przede wszystkim wymiar historyczny. Aktualnie Hezbollah za organizację terrorystyczną w pełni (zarówno skrzydło militarne, jak i polityczne) uznają jedynie cztery państwa: Izrael, Stany Zjednoczone, Kanada i Holandia. Zaś Wielka Brytania i Australia uznają za terrorystyczne wyłącznie skrzydło zbrojne i aparat bezpieczeństwa Hezbollahu, natomiast wykazują przy tym gotowość do dialogu ze skrzydłem politycznym „Partii Boga”24.

Nie sposób też uważać Hezbollahu za rebeliantów czy milicję. Rebelianci występują przeciwko istniejącemu porządkowi państwowemu. Hezbollah wprawdzie posiada własne struktury polityczno-militarne tworząc w ten sposób „państwo w państwie”, ale jednocześnie współtworzy rząd i uczestniczy w procesach państwowych. Ten dualizm aktywności Hezbollahu jest bardzo wyjątkowy w swoim rodzaju. Zdecydowanie Hezbollah jest czymś więcej niż milicją, będącą zwykle organizację paramilitarną,

21 R. Ożarowski, Hezbollah w stosunkach międzynarodowych na Bliskim Wschodzie, Gdańsk 2011, s. 26.

22 Szerzej zob.: A. N. Hamzeh, op. cit., s. 52-57; R. Ożarowski, op. cit., s. 62-65.

23 S. T. Flanigan, M. Abdel-Samad, Hezbollah's Social Jihad: Nonprofits as Resistance Organizations, „Middle East Policy” 2009, vol. XVI, no 2, s. 130-131.

24 R. Ożarowski, Hezbollah w stosunkach międzynarodowych, op. cit., s. 13. 
której celem jest zapewnienie kontroli i porząqku na określonym obszarze. Z resztą sam Hezbollah ostro reaguje na określanie go mianem „milicji” podkreślając, że nie jest żadną milicją a ruchem oporu ${ }^{25}$.

Zatem jakim mianem powinno się określać tak specyficzny podmiot jak Hezbollah? Po pierwsze, jest on partią polityczną i funkcjonuje na terytorium Libanu będąc immanentną częścią sceny politycznej tego państwa. Oznacza to, że jest on podmiotem subpaństwowym, tak jak wszystkie inne partie polityczne wykazujące się aktywnością międzynarodową. Po drugie, Hezbollah spełnia wszelkie kryteria, aby uznawać go za uczestnika transnarodowego. „Partia Boga” posiada ścisłe związki z bardzo liczną i rozsianą na całym świecie szyicką diasporą libańską ${ }^{26}$. Współzależności, jakie łączą diasporę z Hezbollahem przypominają model funkcjonowania korporacji transnarodowej z centrum i jego oddziałami, które tworzą sieć powiązań. W tym przypadku centrum stanowi ścisłe kierownictwo Partii Boga z siedzibą na południowych przedmieściach Bejrutu, a oddziały to pracujące na rzecz Hezbollahu organizacje czy luźne grupy złożone w szczególności z obywateli obcych państw pochodzenia libańskiego. Działalność tych grup najczęściej ma charakter przestępczy (m.in. przemyt diamentów, przemyt i handel narkotykami i bronia, fałszowanie kart kredytowych, oszustwa podatkowe czy pranie brudnych pieniędzy), a spora część zysków z tego tytułu jest w imię religijno-narodowej solidarności przekazywana Hezbollahowi ${ }^{27}$. Po trzecie, Hezbollah, który funkcjonuje zarówno jako uczestnik subpaństwowy, jak i transnarodowy może być ujmowany jako aktor hybrydowy, który łączy w sobie cechy charakterystyczne różnych typów uczestników niepaństwowych ${ }^{28}$. I w końcu po czwarte, aby nie wnikać w liczne kontrowersje i dylematy militarnej aktywności Hezbollahu, które przywołują oskarżenia o terroryzm, bądź gloryfikację ruchu oporu, logiczne jest traktowanie „Partii Boga” w kategorii zmilitaryzowanego aktora niepaństwowego.

\section{HEZBOLLAH JAKO ZMILITARYZOWANY AKTOR NIEPAŃSTWOWY}

Siły zbrojne Hezbollahu są określane mianem „Muzułmańskiego Ruchu Oporu” (arab. Al-Mukawama Al-Islamijja - cyt. dalej MRO) i stanowią obok Instytucji Bezpieczeństwa drugi z pionów Aparatu Militarnego i Bezpieczeństwa „Partii Boga”. MRO składają się z dwóch sekcji: 1) sekcji wykonawczej i rekrutacji; 2) sekcji walki. Ta

25 Tak było np. w odniesieniu do rezolucji Rady Bezpieczeństwa ONZ nr 1559 z 2004 roku, w której wezwano wszystkie libańskie milicje w tym Hezbollah do rozbrojenia się. Zob. Hezbollah official: UN report on militias biased in favor of Israel, http://www.haaretz.com/news/hezbollah-official-un-report-on-militias-biased-in-favor-of-israel-1.284632 (4.11.2011).

${ }^{26}$ Liczbę emigrantów libańskich i ich potomków szacuje się na 12 do $15 \mathrm{mln}$. Szerzej o diasporze libańskiej zob.: The Lebanese and the World: A Century of Emigration, eds. A. H. Hourani, N. Shehadi, London 1993; Politics, Culture and the Lebanese Diaspora, eds. P. Tabar, J. Skulte-Ouaiss, Newcastle upon Tyne 2010.

27 Szerzej zob. R. Ożarowski, Hezbollah w stosunkach międzynarodowych, op. cit., s. 168-191; R. Ożarowski, Specyfika transnarodowej aktywności Hezbollahu w Ameryce Południowej, „Gdańskie Studia Międzynarodowe" 2011, vol. 9, nr 1-2, s. 161-173.

28 Szerzej o koncepcji hybrydowości (synkretyczności) Hezbollahu zob.: R. Ożarowski, Hezbollah $w$ stosunkach międzynarodowych, op. cit., s. 21-27. 
pierwsza zajmuje się ideologiczną indoktrynacją bojowników, celem wzmocnienia ich wiary w prowadzeniu ruchu oporu, druga zaś organizuje szkolenia bojowe, wsparcie medyczne i zaopatruje bojowników w uzbrojenie. Ponadto sekcja walki dzieli się na cztery grupy: 1) męczenników, którzy są gotowi do poświęcenia swojego życia w walce $\mathrm{z}_{\text {wrogami }}{ }^{29}$;2) sił specjalnych, składających się z elitarnej grupy żołnierzy; 3) bojowników z dużym doświadczeniem, potrafiących obsługiwać wszystkie rodzaje broni, w tym wyrzutnie rakietowe; 4) bojowników, którzy posiadają dostateczne doświadczenie, aby brać udział w operacjach zbrojnych, aczkolwiek głównie zajmują się wsparciem logistycznym i medycznym ${ }^{30}$.

Liczba bojowników zarówno tych należących do elity organizacji, jak i tych, którzy dysponują dużym doświadczeniem jest trudna do precyzyjnego oszacowania. Jak twierdzi Anthony Cordesman można przyjąć, że jest to od ok. 2 do 5 tys. osób ${ }^{31}$. Chociaż ten sam autor wskazywał, że trzon sił zbrojnych Hezbollahu tuż przed wybuchem wojny lipcowej w 2006 roku liczył od 2 do 3 tys. bojowników ${ }^{32}$. Uzupełnienie tego stanu, szczególnie na wypadek wojny stanowi około 10 tys. ${ }^{33}$ bojowników powoływanych wtedy pod broń, którzy na co dzień zajmują się np. uprawą roli, ogrodnictwem czy stolarstwem.

Źródłem wiedzy na temat ilości, jakości i rodzaju sprzętu wojskowego „Partii Boga” jest wojna Hezbollahu z Izraelem z 2006 r. (tzw. wojna lipcowa). Z pewnością Hezbollah posiada liczny i dość zaawansowany sprzęt rakietowy. Oficjalnie kierownictwo „Partii Boga” nie podawało stanu liczbowego swoich rakiet, a wypowiedzi w tej sprawie były niejasne ${ }^{34}$. Jednak w oparciu o izraelskie szacunki tuż przed wybuchem wojny w $2006 \mathrm{r}$. Hezbollah posiadał od 10 do 16 tys. rakiet krótkiego zasięgu. Z racji tego, że w czasie trwania konfliktu „Partia Boga” wystrzeliła około 4000 rakiet, liczbę tę można uznać za wiarygodną.

Większość arsenału rakietowego Hezbollahu stanowią rakiety typu Katiusza, mające zasięg około $20-40 \mathrm{~km}$. Ponadto podczas wojny lipcowej na wyposażeniu Hezbollahu były rakiety o zasięgu od 100 do ponad $200 \mathrm{~km}$, m.in. Chaibar 1 czy Zilzal $2^{35}$. Oprócz rakiet ziemia-ziemia Hezbollah użył także rakiet ziemia-woda, takich jak $C-701$ czy bardziej zaawanasowanej technologiczne, skonstruowanej w oparciu o chińskie rozwiązania irańskiej rakiety $\mathrm{C}-802 \mathrm{Nur^{36 }}$. Praktycznie wyłącznymi dostawcami

29 Warto przypomnieć, że od 1999 r. Hezbollah nie wykonał ani jednego ataku samobójczego (operacji męczeńskiej).

30 A. N. Hamzeh, op. cit., s. 70-71.

31 A. H. Cordesman, Arab-Israeli Military Forces in an Era of Asymmetric Wars, Stanford 2008, s. 260 .

32 A. H. Cordesman, G. Sullivan, W. D. Sullivan, Lessons of the 2006 Israeli-Hezbollah War, Washington 2007, s. 17.

33 Ibidem.

34 Hassan Nasrallah w jednym z wywiadów wskazywał, że w 2006 r. Hezbollah posiadał więcej niż 12 tys. rakiet, podając przy tym, że może to być 13 tys., ale także i 20 tys. lub 50 tys. Zob.: Interview with the New TV, August 27, 2006, w: Voice of Hezbollah. The Statements of Sayyed Hassan Nasrallah, ed. N. Noe, London-New York 2007, s. 399.

35 M. Exum, Hizballah at War. A Military Assessment, „Policy Focus” 2006, no 63, s. 6, http://www.lebanonwire.com/0701MLN/Hezbollah_at_war.pdf (21.11.2011).

36 D. Makovsky, J. White, Lessons and Implications of the Israel-Hizballah War, „Policy Focus” 2006, no 60, http://www.washingtoninstitute.org/pubPDFs/PolicyFocus60.pdf (21.11.2011). 
rakiet dla Hezbollahu były Iran i Syria. Podczas wojny lipcowej Hezbollah był również dobrze wyposażony w broń przeciwpancerna. Posiadał m.in. wywodzące się z technologii radzieckiej pociski AT-3 Sagger, AT-4 Spigot czy AT-13 Metis i AT-5 Sprandel oraz granatniki przeciwpancerne RPG-7 i RPG-29. Warty uwagi jest fakt posiadania przez „Partię Boga” francuskich lekkich rakiet przeciwczołgowych MILAN i amerykańskich przeciwpancernych pocisków TOW (ang. Tube-Launched Optically tracked Wire-Guided). Francuskie rakiety Hezbollah otrzymał od Syrii, która nabyła je bezpośrednio od Francji, zaś amerykańskie pociski przekazał Hezbollahowi Iran, który z kolei uzyskał je jeszcze w latach osiemdziesiątych od USA w trakcie wojny iracko-irańskiej ${ }^{37}$.

Skrzydło zbrojne Hezbollahu nie posiada w zasadzie własnego lotnictwa. Jedynie na wyposażeniu „Partii Boga” są bezzałogowe jednostki powietrzne (ang. Unmanned Aerial Vehicle - UAV; w języku angielskim określane także mianem drone) Mirsad 1, będące technologicznym odwzorowaniem irańskiej jednostki - Mohadżer 4. UAV z reguły są wykorzystywane do celów zwiadowczych, chociaż mogą być także wyposażone w ładunki wybuchowe o wadze do $50 \mathrm{~kg}$. Podczas wojny lipcowej Hezbollah wykorzystał swoje Mirsady w działaniach wojennych 7 i 13 sierpnia, przy czym efekty tego były niewielkie ${ }^{38}$.

W kontekście aktywności międzynarodowej nie należy traktować skrzydła zbrojnego Hezbollahu oddzielnie od jego struktur politycznych. Jest to jeden podmiot posiadający ściśle scentralizowane kierownictwo. Zatem, aby określać Hezbollah mianem zmilitaryzowanego aktora niepaństwowego nie zawsze musi on wchodzić w konflikt zbrojny ze swoim przeciwnikiem. Warunkiem sine qua non jest tutaj posiadanie przez Hezbollah swoich sił zbrojnych. Zaś aktywność międzynarodowa „Partii Boga” może wyrażać się między innymi w oświadczeniach politycznych jej liderów, bądź spotkaniach Sekretarza Generalnego „Partii Boga” z przywódcami innej organizacji czy państwa.

\section{ROLA CZYNNIKA MILITARNEGO W POLITYCE HEZBOLLAHU}

Skrzydło zbrojne w polityce Hezbollahu stanowi główną determinantę jego aktywności i zdolności oddziaływania zarówno na scenie politycznej Libanu, jak i w stosunkach międzynarodowych. Obecność MRO w strukturach „Partii Boga” znacznie wzmacnia jej potencjał i mając na uwadze środowisko międzynarodowe Bliskiego Wschodu obliguje przeciwników politycznych Hezbollahu do traktowania go z większym respektem niż jakąkolwiek inną partię polityczną bez skrzydła zbrojnego. Patrząc przez pryzmat Hezbollahu oraz jego sojuszników zasadność utrzymywania MRO może być ujmowana w trzech aspektach.

37 Szerzej o broni przeciwpancernej w posiadaniu Hezbollahu zob.: A. Exum, op. cit., s. 6; J. Dunnigan, Hapless Hezbollah ATGMs Revealed, 7.09.2008, http://www.strategypage.com/dls/articles/20089721428.asp (21.11.2011).

38 U. Rubin, Rocket Campaign against Israel during the 2006 Lebanon War, „Mideast Security and Policy Studies" 2007, no 71, s. 22. 
Po pierwsze, MRO ma niebagatelną wartość historyczną. To skrzydło zbrojne było pierwszym zalążkiem współczesnego Hezbollahu. Wówczas w pierwszej połowie lat osiemdziesiątych inicjatorami rozwoju „Partii Boga” były osoby takie jak: Subhi at-Tufajli, który został potem pierwszym Sekretarzem Generalnym Hezbollahu ${ }^{39}$; Abbas al-Musawi (drugi Sekretarz Generalny „Partii Boga”, zginął w ataku izraelskiego śmigłowca 16 lutego 1992 roku) Husajn al-Musawi (lider muzułmańskiego $A M A L^{40}$, który wzmocnił szeregi formującego się Hezbollahu), Ahmed Kanani (dowódca irańskiego Korpusu Strażników Rewolucji, który zorganizował pierwszą jednostkę bojową Hezbollahu), Szajch Ragheb Harb, czy obecny lider Hezbollahu Hassan Nasrallah (wówczas prowadził on rekrutację do Hezbollahu w szkole teologicznej w Bejrucie). Członkowie MRO, którzy zginęli w działaniach wojennych wstąpili do panteonu męczenników „Partii Boga”. W ideologii Hezbollahu męczennicy zajmują bardzo istotne miejsce. Ku ich pamięci 11 listopada został ustanowiony „dniem męczennika”. Dla przykładu aż do dnia obecnego kierownictwo Hezbollahu przywołuje dokonania i rolę, jaką spełniał Szajch Ragheb Harb, który zginął w 1984 r. w walce z armią izraelską w południowym Libanie. Był on jednym z czołowych dowódców MRO w pierwszym okresie jego istnienia. „Partia Boga” dedykowała Harbowi swój pierwszy polityczny manifest („List Otwarty”) z $1985 \mathrm{r}^{41}$ Męczennikiem został także najstarszy syn Nasrallaha - Hadi, który zginął w walkach z Izraelczykami 13 września 1997 roku. Przy tej okazji Nasrallah w specjalnym oświadczeniu podkreślał wagę męczeństwa mówiąc, że „męczeństwo Hadiego stanowi dowód, że my kierownictwo Hezbollahu, nie oszczędzamy swoich własnych synów; jesteśmy dumni z nich, kiedy idą na front, i podnosimy dumnie głowy, kiedy zostają męczennikami” ${ }^{42}$.

Po drugie, skrzydło zbrojne dla Hezbollahu ma znaczenie egzystencjalne. Można bowiem stawiać pytanie, czym byłaby „Partia Boga” bez MRO? W zasadzie bez swojego skrzydła zbrojnego Hezbollah zostałby zredukowany do poziomu „zwykłej” partii politycznej. W obliczu braku militarnych środków działania nie posiadałby już takiego potencjału i tym samym jego zdolności oddziaływania zostałyby mocno ograniczone. A tak utrzymując swoje skrzydło zbrojne Hezbollah jest cały czas zdolny do prowadzenia działań zbrojnych przeciwko Izraelowi. Według kierownictwa Hezbollahu, co zostało zapowiedziane w Manifeście Politycznym z 2009 r., dalsze prowadzenie ruchu oporu jest niezbędne, gdyż pod izraelską okupacją znajdują się Farmy Sziba’a (14 farm położonych przy granicy izraelsko-libańskiej), wzgórza Kfar Szuba oraz miasto

39 S. at-Tufajli należał do radykalnej frakcji Hezbollahu. Na początku lat dziewięćdziesiątych XX wieku w wyniku zmian, jakie zaszły w Iranie i w samym Libanie, frakcja at-Tufajliego została zmarginalizowana. W 1991 r. przestał być sekretarzem Generalnym „Partii Boga”. W 1998 r. został oficjalnie usunięty z szeregów Hezbollahu. Szerzej o frakcjach wewnątrz Hezbollahu: M. Ranstorp, Hizb'Allah in Lebanon. The Politics of the Western Hostage Crisis, New York 1997, s. 73-78.

40 Muzułmański AMAL (arab. Afwadż al-Mukawama al-Lubnanijja al-Islamijja-Muzułmańskie Oddziały Oporu Libańskiego) - odgałęzienie od AMAL Nabiha Berriego.

${ }^{41}$ The Text of Hizbullah's Open Letter Addressed to The Oppresses in Lebanon and the World, 16 February 1985, w: J. Alagha, Hizbullah's Documents. From the 1985 Open Letter to the 2009 Manifesto, Amsterdam 2011, s. 39.

42 The Martyrdom of Sayyed Hadi Nasrallah, September 13, 1997, w: Voice of Hezbollah, op. cit., s. 173 . 
Ghadżar $^{43}$. Szczególnie silnie akcentowany jest problem Farm Sziba’a, które w $1967 \mathrm{r}$. zostały zajęte przez Izrael. Dla Hezbollahu odzyskanie Farm Sziba'a stanowi ważny cel strategiczny $i$ jest podstawowym argumentem na rzecz utrzymywania swojego skrzydła zbrojnego. Nie brak przy tym głosów ze strony wielu libańskich polityków, że problem Farm Sziba'a w rzeczywistości nie istnieje, a działania Hezbollahu w tej sprawie mają służyć jego własnym interesom ${ }^{44}$.

Prowadzenie walki zbrojnej przez Hezbollah wpisuje się w propagowaną przez ajatollaha Ruhollaha Chomejniego i zaadaptowaną przez „Partię Boga” dualistyczną koncepcję podziału świata na uciśnionych (mustadifin) i prześladowców (mustakbirun) ${ }^{45}$. W ten sposób Hezbollah akcentuje poczucie sprawiedliwości społecznej (al-'Adala al-Idżtima ’ijja) i solidaryzuje się z narodami muzułmańskimi i niemuzułmańskimi na całym świecie ${ }^{46}$.

Po trzecie, aby Hezbollah w dalszym ciągu utrzymywał swoje skrzydło zbrojne leży to w interesie innych państw szczególnie Syrii i Iranu. Syria poprzez Hezbollah warunkuje swoje oddziaływanie w polityce Libanu i pomimo tego, że od 2008 r. oba państwa utrzymują między sobą stosunki dyplomatyczne to wydaje się, że niektórzy politycy syryjscy nie byliby zadowoleni ze stabilizacji państwa libańskiego. Ponadto „zbrojny” Hezbollah jawi się jako sprzymierzeniec Syryjczyków na rzecz ewentualnego odzyskania Wzgórz Golan, za którego działania względem Izraela Syria nie musi brać bezpośredniej odpowiedzialności ${ }^{47}$.

W polityce Iranu Hezbollah spełnia zadania strategiczne. Odpowiednio wyposażone skrzydło zbrojne „Partii Boga” pozwala na utrzymywanie permanentnie newralgicznej sytuacji na granicy izraelsko-libańskiej. $Z$ tego powodu w interesie Iranu leży dozbrajanie Hezbollahu tak, aby mógł on stanowić realne zagrożenie dla Izraela.

Warto przy tej okazji wskazać, że tak jak Iranowi i Syrii zależy na utrzymaniu zbrojnego skrzydła Hezbollahu, tak Izrael i USA domagają się jego rozbrojenia. Od wielu lat, często z inicjatywy Stanów Zjednoczonych Rada Bezpieczeństwa ONZ przyjmuje rezolucje, które wzywają do rozbrojenia wszystkich zbrojnych grup w Libanie, m.in. nr 1559 z 2004 roku, nr 1680 i 1701 z 2006 roku, które potwierdzają warunki przyjęte $\mathrm{z}$ rezolucji $\mathrm{nr}$ 1559. I chociaż Hezbollah w kontekście rozbrojenia nie jest tam wymieniony z nazwy to pozostaje on ,ukrytym” adresatem tych ustalen ${ }^{48}$.

43 Manifest Polityczny z 30 listopada 2009 r., w: R. Ożarowski, Hezbollah w stosunkach międzynarodowych, op. cit., s. 223. Północną część miasta Ghadżar w listopadzie 2010 r. władze Izraela przekazały Libanowi.

${ }_{44}$ Zob. m.in.: M. Hatoum, Jumblatt questions Hizbullah allegiance, „Daily Star”, 9.01.2006.

45 Szerzej o dualistycznej percepcji świata w ideologii Hezbollahu zob.: A. Saad-Ghorayeb, Hizbu'llah. Politics \& Religion, London-Sterling 2002, s. 16-25; R. Ożarowski, Hezbollah w stosunkach międzynarodowych, op. cit., s. 58-59; A. N. Hamzeh, op. cit., s. 42-43.

46 A. Saad-Ghorayeb, op. cit., s. 16.

47 Ze względu na trwające od stycznia 2011 r. protesty i rozruchy społeczne w Syrii przeciwko prezydentowi Baszirowi al-Asadowi i partii Baas i tym samym prawdopodobieństwo zmiany rządów w tym państwie, ocena polityki syryjskiej względem Hezbollahu dotyczy cały czas utrzymującego się u władzy reżimu B. al-Asada.

48 Szerzej o kwestii rozbrojenia Hezbollahu zob.: A. Saad-Ghorayeb, Hizbollah's Outlook in the Current Conflict, „Policy Outlook”, Carnegie Endowment for International Peace, August 2006, http://carnegieendowment.org/2006/08/11/hizbollah-s-outlook-in-current-conflict/wxx (1.12.2011); 


\section{HEZBOLLAH JAKO ZMILITARYZOWANY AKTOR NIEPAŃSTWOWY W RELACJACH Z PAŃSTWEM}

Hezbollah od początku swojego istnienia prowadzi politykę względem państw i jednocześnie stanowi podmiot, wobec którego państwa wykazują dużą aktywność w stosunkach międzynarodowych. Relacje reprezentującego zmilitaryzowanego aktora niepaństwowego Hezbollahu z państwami mogą stanowić egzemplifikację współzależności, strategii działania i metod stosowanych w realizacji tej strategii zarówno ze strony jednej, jak i drugiej strony. Pomaga to w zrozumieniu współczesnej dynamiki rozwoju aktorów niepaństwowych dla których państwo jest naturalnym punktem odniesienia.

„Partia Boga” jest na tyle wyjątkowym w swoim rodzaju zmilitaryzowanym aktorem niepaństwowym, że pojawia się przy tym potrzeba wyodrębnienia dwóch grup państw, których relacje z Hezbollahem można poddawać analizie. Do pierwszej grupy należy zaliczyć wyłącznie Liban, do drugiej zaś wszystkie pozostałe podmioty państwowe. Podział taki jest warunkowany specyficzną rolą i miejscem, jakie zajmuje Hezbollah na scenie politycznej libańskiego państwa.

Hezbollah definiuje siebie jako muzułmański ruch oporu i podkreśla przy tym swoją libańską tożsamość. Już na początku lat dziewięćdziesiątych XX wieku kierownictwo Hezbollahu zaczęło propagandowo kształtować swój libański wizerunek, tak aby bezpośrednie związki z Iranem nie odgrywały głównej roli w identyfikacji „Partii Boga”. Dowodem tego jest między innymi udzielony w 1992 r. wywiad przez Nasrallaha arabskiej „Al-Watan Al-Arabi”, w którym wyraźnie podkreślał, że Hezbollah nie jest irańską grupą w Libanie, a bojownicy Hezbollahu nie są obywatelami irańskimi ${ }^{49}$. W następnych latach praktyką już się stało, że Hezbollah w programach wyborczych zwracał się do wszystkich Libańczyków bez względu na ich wyznanie. Zaś w „Manifeście Politycznym" z 2009 r. Hezbollah przedstawił Liban jako wspólną ojczyznę, która w jego pragnieniu ma być stabilna, silna, sprawiedliwa i zjednoczona ${ }^{50}$.

Częste odwołania Hezbollahu do patriotyzmu czy libańskości z jednej strony podkreślająjego narodową postawę, jednak z drugiej strony są one wykorzystywane do kamuflowania partykularnych działań „Partii Boga” choćby wobec Izraela. Wszelkie akcje zbrojne usprawiedliwiane są prowadzeniem ruchu oporu w celu wyzwolenia pozostającego jeszcze w granicach Izraela terytorium Libanu. W ten sposób Hezbollah uzurpuje sobie prawo do działania w imieniu państwa. Problem ten jest o wiele bardziej złożony gdyż Hezbollah w kontekście państwa libańskiego występuje w podwójnej i sprzecznej ze sobą roli. Funkcjonuje jako uczestnik subpaństwowy ze strukturami quasi-państwowymi i realizuje swój interes partykularny oraz jednocześnie współtworzy struktury i instytucje państwowe, zasiadając w parlamencie libańskim czy aktualnie współtworząc rząd tego kraju.

B. J. Talbot, H. Harriman, Disarming Hezbollah, „Mediterranean Quarterly” 2008, vol. 19, no 4, s. 29-53; B. Y. Saab, Rethinking Hezbollah's Disarmament, „Middle East Policy” 2008, vol. XV, no 3, s. 93-106.

${ }^{49}$ Hezbollah is not an Iranian Community in Lebanon, w: Voice of Hezbollah, op. cit., s. 91-92.

50 Manifest Polityczny, op. cit., s. 221-222. 
Sytuacja, w której Hezbollah ma swobodę działania z wykorzystaniem swojego potencjału militarnego jest dla niego niezwykle korzystna. Tym bardziej, że jako aktor niepaństwowy operujący na obszarze Libanu nie ponosi pełnej odpowiedzialności za wydarzenia, jakie zachodzą na tym terytorium - odpowiedzialność taką ponosi Liban jako państwo. Tak samo było w przypadku ataków na terytorium Izraela dokonywanych przez fedainów palestyńskich ze Strefy Gazy czy z Zachodniego Brzegu Jordanu, kiedy obszary te jeszcze przed 1967 r. znajdowały się kolejno w granicach Egiptu i Jordanii. Władze Izraela kierowały wówczas pretensje do rządów tych państw.

W prowadzeniu walki przeciw Izraelowi Hezbollah od wielu lat efektywnie wykorzystuje swój status aktora niepaństwowego, wchodząc z nim w konflikt asymetryczny. „Partia Boga” ma świadomość przygniatającej przewagi militarnej i technologicznej przeciwnika i z tej przyczyny jest zmuszona stosować takie metody, aby wyrównać różnicę potencjałów. Kulminacją tego była „wojna lipcowa” z 2006 r., którą Izrael przegrał. Hezbollah natomiast wykazał się znakomitym przygotowaniem taktycznym, m.in. zreorganizował strukturę dowodzenia jednostek bojowych, które uzyskały dużą autonomię działania; właściwie przygotował system obrony z odpowiednią lokalizacją rakiet, zastosowaniem kamuflażu, fortyfikacji, bunkrów i pułapek; wykorzystał geograficzne uwarunkowania terenu; zadbał o mentalne przygotowanie swoich sił zbrojnych oraz przeprowadził szczegółowe rozpoznanie strategii działania przeciwnika z uwzględnieniem stanu jego sił zbrojnych i nastrojów społecznych towarzyszących kampanii wojennej ${ }^{51}$. Potwierdza to, iż aktorzy niepaństwowi prowadzący działania zbrojne stanowią dla państw jedno z największych wyzwań w XXI wieku. Okazuje się przy tym, że zaawansowanie technologiczne armii państwa i jej najnowocześniejsze wyposażenie nie gwarantuje wcale ostatecznego sukcesu, kiedy po drugiej stronie walki przeciwnik ma status niepaństwowy.

Warto przy tej okazji wskazać, że tak jak niektóre państwa uczestniczące w konflikcie asymetrycznym z uczestnikiem niepaństwowym są skazane na liczne trudności i straty, tak inne wykorzystują współczesną specyfikę tych konfliktów, aby odnosić z tego tytułu korzyści. Należy zatem postawić pytanie: Czy zbrojne skrzydło Hezbollahu przetrwałoby bez pomocy innych państw? Odpowiedź wydaje się jednoznaczna - bez zaopatrzenia w broń szczególnie ze strony Iranu, a także Syrii, Hezbollah nie byłby w stanie prowadzić wojny z Izraelem na taką skalę jak w 2006 r. Tym samym bez wsparcia zewnętrznego MRO mógłby przestać istnieć. Wniosek z tego jest taki, że Hezbollah jako zmilitaryzowany aktor niepaństwowy korzysta z pomocy państw, aby prowadzić walkę z innymi państwami. Leży to $\mathrm{w}$ interesie samego Hezbollahu, jak i państw które go wspierają. Ujawnia się tutaj dość charakterystyczny schemat współczesnych konfliktów międzypaństwowych prowadzonych w sposób pośredni. Obecnie państwa rzadko decydują się na bezpośrednie działania wojenne i preferują

51 Szerzej o wojnie lipcowej jako konflikcie asymetrycznym Hezbollahu z Izraelem zob.: S. Biddle, J. A. Friedman, The 2006 Lebanon Campaign and Future of Warfare: Implications for Army and Defense Policy, Strategic Studies Institute, September 2008; R. Ożarowski, Hezbollah w stosunkach międzynarodowych, op. cit., s. 96-121; The War on Lebanon. A Reader, ed. N. Hovsepian, Northampton 2008; A. Harel, A. Issacharoff, 34 Days. Israel, Hezbollah and the War in Lebanon, New York 2008 . 
rozwiązania, w których wspierany przez nie logistycznie i finansowo aktor niepaństwowy prowadzi działania wobec innego, wrogiego politycznie państwa.

$* * *$

Pomimo zachodzących zmian w stosunkach międzynarodowych posiadanie środków militarnych i zdolność ich wykorzystywania stanowi racjonalne kryterium klasyfikacji podmiotowej uczestników niepaństwowych. Okazuje się, że aktorzy niepaństwowi, którzy posiadają swoje siły zbrojne, bądź w swoim działaniu posługują się bronią mają istotny wkład w kształtowanie rzeczywistości międzynarodowej i w wielu przypadkach stanowią niebagatelne wyzwanie w polityce państw.

Przykład Hezbollahu, którym Autor posłużył się w niniejszym artykule, pokazał jak istotne dla funkcjonowania i realizacji celów tego aktora niepaństwowego jest posiadanie przez niego własnego skrzydła zbrojnego. Hezbollah pozbawiony potencjału militarnego nie miałby większych zdolności do oddziaływania w stosunkach międzynarodowych, a analiza jego aktywności praktycznie pozbawiona byłaby uzasadnienia.

Jak można zaobserwować na przykładzie Hezbollahu, tego typu zmilitaryzowany aktor niepaństwowy w relacjach z państwami efektywnie wykorzystuje swój status. Co więcej jeśli byłaby sposobność, aby Hezbollah mógł zmienić swój status np. w wyniku proklamacji własnego państwa to w ten sposób automatycznie pozbawiłby się swojej „niepaństwowości”, co stanowiłoby krok ku destrukcji tego podmiotu. Osiagnięcie statusu państwa spowodowałoby utratę przez Hezbollah wszelkich przywilejów i korzyści czerpanych z tytułu aktora niepaństwowego. Wniosek z tego jest taki, że Hezbollahowi $\mathrm{i}$ innym podobnym mu zmilitaryzowanym aktorom niepaństwowym nie opłaca się być państwem i korzystniej jest posiadać struktury polityczno-militarne oraz kontrolować określone terytorium jako uczestnik niepaństwowy. W ocenie Autora jest to podstawowy argument, dla którego kierownictwo Hezbollahu za wszelką cenę będzie dążyć do utrzymania istniejącego status quo, pozwalającego na oddziaływanie na scenę polityczną Libanu przy jednoczesnym dysponowaniu środkami militarnymi i prowadzeniu aktywności międzynarodowej nie obciążonej odpowiedzialnością jaką ponosi państwo.

\section{STRESZCZENIE}

W artykule podjęto się próby zdefiniowania i sklasyfikowania „zmilitaryzowanego aktora niepaństwowego" wskazując przy tym, że termin ten obejmuje szeroką grupę podmiotów niepaństwowych takich jak: partie polityczne ze swoim skrzydłem zbrojnym, międzynarodowe grupy przestępcze, organizacje terrorystyczne, prywatne firmy wojskowe czy ruchy narodowo-wyzwoleńcze. Dyskusyjna pozostaje obecność w tej grupie kontyngentów wojskowych rządowych organizacji międzynarodowych.

Posługując się przykładem libańskiego Hezbollahu, który od początku swojego istnienia dysponuje własnymi siłami zbrojnymi i wykazuje dużą aktywność w stosunkach międzynarodowych, dokonano próby charakterystyki zmilitaryzowanego aktora niepaństwowego. Okazało się, że tego typu aktorzy jak Hezbollah dobrze adaptują się do nowych zjawisk i procesów międzynarodowych; stanowią spore wyzwanie dla państw, które dysponują zaawansowanymi siłami zbrojnymi oraz jednocześnie są wykorzystywani przez inne państwa do realizacji swoich 
celów. Zatem rola takiego uczestnika we współczesnych stosunkach międzynarodowych ma charakter złożony.

\title{
SPECIFICITY OF A MILITARIZED NON-STATE ACTOR IN CONTEMPORARY INTERNATIONAL RELATIONS. THE CASE OF HIZBALLAH
}

\begin{abstract}
In this paper Author has defined and classified a „militarized non-state actor” pointing that this term comprises many different non-state actors like for example: political parties with their military wings, international criminal groups, terrorist organizations, private military companies or independence movements. It is also a disputable issue if armed forces deployed within governmental organizations (like the UN or NATO) are treated as militarized non-state actors or not.

Lebanese Hizballah has been used here as an example to describe the specificity of a militarized non-state actor. Hizballah has its own armed forces and has been active in international relations. As a result of the analysis, such actors like Hizballah are well adoptable to new phenomena and processes which occurred in international relations, they are challenging states in their activities, moreover: they are used in many cases by states to achieve their goals. It shows the ambiguity in functioning of such a non-state actor.
\end{abstract}

